\title{
DAMAGES GIVEN IN EQUITY IN LIEU OF A SPECIFIC PERFORMANCE.
}

In the June number I discussed the subject of partial specific performance. 1 In cases of partial specific performance, the defendant, not being able to substantially perform his contract, is obliged by the court to perform as far as he is able. It may be, however, that the defendant is unable to perform his promises even in part. In such a case the only possible obligation the law can fasten on the defaulting party is the payment of money, or the conveyance of other property, as damages for the default. The court of equity is not ordinarily a court in which money damages for breach of contract can be recovered; yet, under certain circumstances, where the defendant cannot perform his contract, equity will retain the bill for the purpose of giving the plaintiff damages. As in such cases the defendant has no right to any relief against the plaintiff, and as the foundation of the plaintiff's rights is a contract, we may regard the action of the court as another exception to the rule that the remedy of specific performance must be mutual, though, of course, strictly speaking, the plaintiff does not obtain what is usually called specific performance. He does, however, obtain relief in equity.

The leading case in which we find a court of equity retaining a bill for a specific performance in order to assess damages is Denton v. Stewart, ${ }^{2}$ a case decided by Lord Kenyon in 1786 . There, A. and B. agreed by parole that A. should buy a certain house from B. A. went into possession, but B. brought an action of ejectment against him and turned him out. The parole agreement could not have been set up

${ }^{1}$ At page 329. Other papers on the specific performance of contracts and the defence of want of mutuality will be found: AM. LAw. REG., June, I901, p. 3I9; July, I90I, p. 383; August, I90I, p. 447; September, I90I, p. 507; October, I901, p. 559; February, I902, p. 65; May, I902, p. $25 \mathrm{I}$.

2 I Cox. Eq. 258, I786, s. c. I7 Ves. 276 , note. 
at law as a defence to the action of ejectment. ${ }^{3}$ After the ejectment, B. sold the house to a stranger for value and apparently without notice of A.'s right. Probably after this sale, but certainly without knowledge of it, A. brought his bill against $B$. for a. specific performance, setting forth previous possession as sufficient part performance to take the parole contract out of the statute of frauds. ${ }^{4}$ Lord Kenyon thought there had been sufficient part performance to entitle the plaintiff to specific performance, had the land not been sold. He ordered that it should be referred to a Master to inquire what damage the plaintiff had sustained by the defendant's non-performance, and that this damage, together with the costs of the suit, should be paid by the defendant. ${ }^{5}$

Lord Kenyon might have cited in support of his action a case then almost a hundred years old, namely, Hedges $\mathrm{v}$. Everard. ${ }^{6}$ There a man, before his marriage, settled on himself and his intended wife certain lands, and covenanted that they were and would remain of a certain value. On the death of the husband, the wife brought her bill to have the defect in the lands ascertained and made good out of her late husband's real or personal estate. It was objected that the bill sounded only in damages, yet the court held that a Master could inquire into the defect and report, when the court "may decree such defect to be made good, or send to be tried at law upon a Quantum damnificatus." Though this

- This at least was the opinion of the judges of the King's Bench at the time: see I Cox. Eq., p. 258.

"In the note by Sir Samuel Romilly, I7 Ves. 276, it is stated that the fact of the assignment to a third person did not appear in the answer, but was first ascertained from the defendant's counsel. Lord Eldon seems to assert that the sale was made after the bill was filed, as in Todd v. Gee, I7 Ves. 273, 1810, 278, he makes the assertion that in Denton v. Stewart the defendant had put it out of his power to perform the agreement pending the suit. It may be, however, that Lord Eldon's opinion, that otherwise the case is bad law, influenced his opinion of the facts.

- Page 258. That the case is not better reported is -probably due to the fact that it was not much contested, as the damage to the plaintiff seems to have been only nominal. See remarks of Lord Eldon in Todd v. Gee, it Ves., p. 277.

' I Eq. Cas. Abr. 18, pl. 7, 1699. 
case is an authority tending to support Lord Kenyon's action in Denton v. Stewart, it can hardly be said to deprive the later case of its position as the earliest case in which damages were given by a court of equity where a specific performance was impossible. It is a long step from giving final relief to a jointress who had married on the faith of the provision, to an award of damages to an ordinary purchaser who seeks specific performance but cannot have it owing to a conveyance by a vendor to a third person.

In Greenaway v. Adams, ${ }^{7}$ Sir William Grant, though he frankly says he does not understand the principle on which Lord Kenyon proceeded, unwittingly extends the principle of that case. In the case before him the plaintiff had agreed to take from the defendant the assignment of the residue of a lease. The defendant had offered to convey, but the plaintiff had refused to accept on the ground that the lease contained a clause forfeiting the same in case of an assignment without the consent of the lessor, and there was no evidence that the lessor had consented. The defendant, contending that the consent of the landlord was not necessary, assigned the lease to a third person. There would appear to be no question but that the plaintiff, at the time he brought his bill, knew of this assignment. In Denton v. Stewart no such knowledge on the part of the plaintiff appears. Yet Sir William Grant says: "The case of Denton v. Stewart is a decision in point, . . . the species facti is precisely the same as in this case. : . For in that the inability of the party to perform the contract grew out of an act done by the party, after the contract had been entered into."8 $\mathrm{He}$ also points out that there is no difference in principle whether the damages are assessed by an issue quantum damnificatus or by a Master, as the real question is whether the court of equity. can give relief in damages at all. Precisely the same order, was made as in Denton v. Stewart. ${ }^{9}$ In Todd v. Gee ${ }^{10}$ there

'12 Ves. 395, 1806.

- Pp. 401, 402.

'The next year in Grwillim v. Stone, 14 Ves. 128, 1807, Sir William Grant refused to give damages in addition to cancellation where the plaintiff sought cancellation of a contract to purchase the defendant's land, on account of the vendor's defective title, and also damages for the 
was an agreement to purchase land. There was considerable doubt in regard to the power of the vendors, who were executors, to sell. The vendee prayed for a specific performance, if a good title could be made, or damages. The defendants demurred to the relief. Lord Eldon, regarding the plaintiff as having a right to have the possibility of the defendant making a good title ascertained, overruled the demurrer. In the course of his opinion, however, he says that, in a case circumstanced as the one before him, if the defendant could not make a good title, the plaintiff could not have the bill retained to assess damages, and points out that, "In Denton v. Stewart the defendant had it in his power to perform the agreement; and put it out of his power pending the suit,"11 asserting that it is only on this ground that Lord Kenyon's decision can be supported. Though, as we see, Lord Eldon did not in Todd v. Gee formally overrule Denton v. Stewart, and did not even express the opinion that he would not follow Lord Kenyon in a similar case, it is probable that, at the time, Todd v. Gee was regarded as practically doing away with the possibility of recovering damages in equity where specific relief could not be given. ${ }^{12}$ Thus in Sainsbury v. Jones, ${ }^{13}$ a case decided in 1839 , Lord: Cottenham says : "I certainly recollect the time at which therewas a floating idea in the profession that this court might: award-compensation for the injury sustained by the nonperformance of a contract, in the event of the primary relief for a specific performance failing. . . . This, however, lasted but a short time, for, . . . Lord Eldon, in Todd v. Gee, expressly overruled Denton v. Stezvart; and from that time there has not, I believe, been any doubt upon the breach. He refers to his hesitancy in Greenaway v. Adams, but properly points out that the bill before him is of a different nature. The case does not indicate that he was inclined to believe that his action in Greenaway v. Adams was incorrect.

${ }^{30}$ I7 Ves. 273, I8Io.

12 Page 278.

I2 In Blore v. Sutton, 3 Mer. 235, 1818, 247, Sir William Grant said : "The competency of the court of equity to give damages for the nonperformance of an agreement has, notwithstanding the case of Denton v. Stewart, been questioned by very high authority." The question was not directly before him.

${ }^{13} 5$ My. \& Cr. I, 1839. 
subject."14 In view of this final position of the English courts, had it not been for their effect on the American cases, Denton v. Stewart and Greenaway v. Adams would have for us merely historical interest.

In England the Parliament has by statute revised and very much expanded the principle that a court of equity may give the plaintiff damages, where an award of specific relief is impossible. The first step in this direction was Lord Cairn's Act, passed in I858. This provided, that, "In all cases in which the Court of Chancery has jurisdiction to entertain an application . . ' for specific performance of any covenant, contract, or agreement, it shall be lawful for the same court, if it shall think fit, to award damages to the party injured, either in addition to or in substitution for such . . . specific performance, and such damages may be assessed in such manner as the court shall direct."15 As construed by the courts this Act did not permit the Court of Chancery to give damages in a case where the plaintiff asked - for a specific performance of a contract not the subject of such relief as a contract for personal services. ${ }^{16}$ It was also

"Page 3. In the case before Lord Cottenham, C. contracted as agent of $B$. and $D$. to sell land to $A$. $B$. and $D$. denied the agency. $A$. brought his bill against B., C. and D. for specific performance, or if that was impossible, that the bill should be retained against $C$. and damages awarded. The bill was dismissed. The case is distinguishable from Denton v. Stezwart. The defendant had not put it out of his power to fulfil the contract, and the plaintiff, when he brought his bill, knew of the defendant's inability to perform. This knowledge is not adverted to in any of the early English cases as proving a barrier to the recovery of damages. Later, however, it was held by Lord Romilly as sufficient to defeat the plaintiff's right to compensation for defects in title, if these defects were known to the plaintiff at the time he brought his bill: Maw v. Topham, 19 Beav. 576, 1854. It is not unlikely that Lord Romilly's decision would be followed in most of the United States, where the defendant in addition showed that he was willing to convey as far as he could before bill brought: Compare Rankin v. Hammond, $25 \mathrm{~Pa}$. C. C. 45 (1900) with the decisions in the text, infra on the effect of the plaintiff's knowledge, at the time he brought his bill, of the impossibility of the defendant's performance.

${ }^{15} 21$ and 22 Vict., c. $27, \S 2$.

${ }^{18}$ Rogers v. Challis, 27 Beav. 175, 1859, I80; White v. Boby, 26 W. R. I33, I877. (A case decided after the Judicature Act, but which discusses, page 134, the effect of Lord Cairn's Act: Compare note 21, infra.) 
intimated by Lord Romilly, following hịs thought expressed in Maze v. Topham, ${ }^{17}$ that the plaintiff, at the time he brings his bill, ought not to know of the inability of the defendant to perform his agreement. ${ }^{18}$ These interpretations of Lord Cairn's Act have not now in England any importance, because the Act itself, though it may not be formally abolished, ${ }^{19}$ is practically superseded and extended by the Judicature Act. This later statute provides that, "The High Court of Justice and Court of Appeal, respectively . . . in. every cause or matter pending before them . . . shall grant .. . . all such remedies whatsoever as any of the parties thereto may appear to be entitled to in respect to any and every legal claim properly brought forward by them respectively in such cause or matter; so that, as far as possible, all matters so in controversy between the said parties, respectively, may be completely and finally determined, and all multiplicity of legal proceedings concerning such matters avoided."20 Under this sweeping provision, it would appear to be immaterial whether the plaintiff asked for specific performance or damages, whether he knew of the facts rendering specific performance impossible at the time he brought the bill or not, or even whether, irrespective of those facts, it was a case for specific performance at all. Provided the plaintiff shows that he has a legal claim, the court will end the controversy between the parties, by giving the plaintiff the relief to which, under all the circumstances of the case, he is entitled. ${ }^{21}$

${ }^{17}$ Ig Beav. 576, I854, see supra, note I4.

${ }^{2 s}$ Howe v. Hunt, 8 Jur. N. S., Pt. I, 834,1862 . The opinion as a whole is confused and most unsatisfactory.

${ }^{10}$ Lord Cairn's Act was formally repealed by 46 and 47 Vict., c. 49 , schedule, but $\S 5$ of this act provides: "The repeal effected by this act shall not affect $(b)$ any, jurisdiction... established . . . under any enactment repealed by this act." In Sayers v. Collyer, L. R. $28 \mathrm{Ch}$. Div. I03, I884, Baggallay thought that this clause preserved the second section of Lord Cairn's Act.

${ }^{20} 36$ and 37 Vict., c. $66, \S 24$ (7).

${ }^{21}$ See, for language similar to that used in the text, Sayers.v. Collyer, L. R. 28 Ch. D. I03, I884; also Elmore v. Pirrie, 57 L. T. n. s. 333 , 1887. In White v. Boby, 26 W. R. I33, 1877, Lord Jessel assumes that the Judicature Act does not enable one who asks for specific performance of a contract of which the court of equity does 
In the United States the development of the law on the subject under discussion has differed from that in England in two vital particulars. On the one hand, Denton v. Stereart, with certain limitations, has been generally followed; on the other, statutes embodying the principle of this decision have only been adopted in some of the States, and, where adopted, have not always received a liberal interpretation. Perhaps the earliest American case is $M^{\prime}$ Connell v. Dumlap. ${ }^{22}$ There, the Court of Appeals of Kentucky declared that, if in a bill for a specific performance of a contract to convey land, the deferidant could not make title to more than one-half the acreage, the trial court should direct an issue to a jury to ascertain the value of the land. ${ }^{23}$ It will be noted that this was following without qualification the principle of Denton v. Stewart. The same court, however, a few years later, in Fisher v. Kay, ${ }^{24}$ were the first to intimate what we may regard as the chief qualification to the doctrine of the English case. The plaintiff and the - defendants' ancestor agreed to exchange lands. The plaintiff had conveyed his land to the defendants; but they had conveyed their land to a third person. This fact was known to the plaintiff at the time he brought his bill for specific performance, a return of his own land, or damages. The court intimate that had the plaintiff not asked for a reconveyance of the land conveyed by him to the defendants, to which equitable relief he was unquestionably entitled, there might be some force in the objection that the plaintiff knew, at the time he brought the bill, of the impossibility of securing the land to which he was entitled under the contract. ${ }^{25}$

not have jurisdiction; as a contract for personal services, to have his bill retained for the purpose of assessing damages. Query, however, if the direct language of the act and the language of the later decisions are not contra to Jessel's assumption?

$=$ Hard. 4I, Kty. I805.

${ }^{2}$ If the plaintiff would accept the half that could be conveyed, the issue should be the value of the half not conveyed. The plaintiff, however, was considered to have the right to insist on full compensation in damages in a court of equity. The decision was followed by the same court in Rankin v. Maxwell, 2 A. K. Marsh. 488, Kty. I820.

2A 2 Bibb. 434, Kty. I8II.

2 Page 426. 
A similar intimation, that the knowledge of the plaintiff at the time of bringing the bill that he cannot have specific performance would be fatal to its retention for the purpose of assessing damages, was made by Chancellor Kent, in Hatch v. Cobb, ${ }^{28}$ while in Kempshall v. Stone ${ }^{27}$ he made a positive decision to this effect. This decision has been followed. ${ }^{28}$ In the cases cited the defendant, after the contract was entered into, disabled himself from fulfilling it. Where, besides the knowledge of the defect by the plaintiff at the time he brings the bill, the defect itself existed from the time of the inception of the contract, there is, perhaps, an additional reason for dismissing the bill. I have collected in the note the cases presenting this combination of facts. ${ }^{29}$ It has also been held that if, at the time the plaintiff brings his bill, he knows facts from which, had he known the law, he might have inferred that the defendant could not perform his promise, the bill cannot be retained for damages. Thus, where four out of five tenants in common united in a lease, and the lessee agreed to sublet part of the premises, the prayer of the sublessee for specific performance was denied, because the original lease was invalid, not being signed by all the tenants in common, and the bill was not retained to assess damages, because the plaintiff ought to have known of this rule of law when he began his suit. ${ }^{30}$ Other cases, however, have refused to go so far as this. Thus, in Slangh-

${ }^{2} 4$ Johns. Ch. 559, N. Y. 1820 .

${ }^{27} 5$ Johns. Ch. I93, N. Y. I82I, compare Slaughter v. Tindle, I Litt. 358, Kty. 1822 .

${ }^{2}$ Carroll v. Willon, 22 Ark. 32, 1860, 52, 53, 54; Doan v. Mauzey, 33 III. 227, I864; Semble Summerlin v. Fronterizer Silver Mining Co., 4I Fed. 249, I890; Gupton v. Gupton, 47 Mo. 37, I870 (dicta). But see Boden v. Curtis, 2I A. 472, N. J. I89I.

20 Sellers v. Green, I72 Ill. 549, 1898, 558 (reversing on another point 64 Ill. App. 505, 1896); Mack v. McIntosh, 181 Ill. 633, 1899; Bartol v. Shaffer, 7 North. Co. R. $207, \mathrm{~Pa}$. C. C. I900. The principle is admitted in $M c Q u e e n$ v. Chouteau, $20 \mathrm{Mo.} 222,1855$. A fortiori when at the time of the contract the plaintiff knew that the fulfillment of the defendants' promise depended on the will of a third person, the bill cannot be retained to assess damages: Hill v. Fiske, $38 \mathrm{Me}$. 520, 1854; Hulbut v. Kautzler, II2 Ill. 482 , 1884.

${ }^{30}$ Tainter v. Cole, 120 Mass. 162, 1876. See also Jontes v. Tunis, 37 S. E. $84 \mathrm{r}$, Va. Igor. 
ter v. Tindle, ${ }^{31}$ the plaintiff in his bill set out that he had doubts about the defendant's title, and asked that, if a specific performance could not be awarded, a decree for compensation in damages be made. The doubts proving well founded, the bill was retained and compensation awarded. It can hardly be maintained that this decision is contrary to that of Chancellor Kent in Kempshall v. Stone. Merely to doubt the defendant's ability to fulfill his agreement, is not to know that it is impossible for him to do so; but the case is unquestionably contra to the Massachusetts case of Tainter v. Cole, just referred to, provided in the - Kentucky case the plaintiff knew all the facts which rendered specific relief impossible, and merely had doubts about the legal conclusion to be deduced from those facts. ${ }^{32}$ It would appeal to the writer that knowledge of the fact that a decree for specific performance cannot be had should be fatal to the plaintiff's right to recover damages in the equity suit. So long as a given jurisdiction recognizes the separation of law and equity, the mistake of the forum in which one proceeds should be fatal to the action. If this were not so we should have one forum administering common law as well as equity. This may be desirable, but it is too fundamental a change to be made by the courts. Such a change should be the result of legislative action. It would also appear that this mistake is none the less if facts are known to the plaintiff at the time he brings his bill, from which, if he knew the law, he would have known that equitable relief was impossible.

21 I Litt. 358, Kty. I822.

22 See, for a case in which the defendant seems really to have known that specific performance was impossible and yet the bill was retained to assess damages, Gibbs v. Champion, 3 Ohio, 355, 1828. In Huffman v. Bradshaw, I7 $\mathrm{Pa}$. Sup. Ct. 205, I900, aff. 30 Pitts. Leg. J. $38 \%$, I900, the plaintiff brought his bill against a husband and wife, asking for specific performance of an agreement to convey land. He alleged that the refusal of the wife to join in the deed was at the instigation of the husband. Proof of this failed. In Pennsylvania, one who agrees to buy land from a married man can.refuse to take if the wife will not join in the deed, but the court will not give him a decree against the husband with compensation for the inchoate right of dower in the wife. The plaintiff did not wish a deed signed by the man alone. The court on this refusal gave money damages to the plaintiff. The question of jurisdiction was not discussed. 
Ignorance of the law on the part of a litigant ought not, of itself, to be a foundation for a court's jurisdiction. On the other hand, where one brings a bill for specific performance who is ignorant of facts, or not sure of facts, which render equitable relief impossible, he does not knowingly or negligently mistake his tribunal. It is not the plaintiff's business to investigate all the facts and make sure that the defendant can be made to perform his contract, before he brings his bill. The defendant is in default, and this default renders it impossible for the court to give the equitable relief asked. There exists, therefore, a real if not necessarily a good reason for not asking the innocent plaintiff to withdraw his present suit, and begin all over again in another forum. ${ }^{33}$

With the limitation just discussed, the principle of Denton v. Stewart meets, if not universal, very general favor. Shortly after his decisions in Hatch v. Cobb and Kempshall v. Stone, Chancellor Kent, in Woodcock v. Bennet, ${ }^{84}$ decreed, that in view of the fact that the defendant had disabled himself from performing his contract, the plaintiff had a right to have it referred to a Master to determine his damages. ${ }^{35}$ Some years later in a like case, Assistant Vice-Chancellor Murray took a similar action. ${ }^{36}$ On appeal to the Supreme Court the case was reversed, the court practically reverting to the position of Lord Eldon, that chancery ought only to retain the bill for the purpose of compensation in

4 There is one case in which the action of the plaintiff pending suit made it impossible for the court to give equitable relief, and yet the court retained the bill to assess damages. The case is that of Attorney General v. Proprietors of Deerfield River Bridge, 105 Mass. I; 1870. The defendant company was obliged by its charter to keep a certain bridge in repair. The court by statute had, on information filed, a right to enforce the obligation. The Attorney General, on behalf of the selectmen of the town in which the bridge was situated, brought an information. During the pendency of the suit the town repaired the bridge. The court retained the bill for the purpose of assessing damages.

" I Cow, 7II, I823. In Hatch v. Cobb he had sympathized with Lord Eldon's criticism of Denton v. Stewart.

$\approx$ This action was approved by Woodworth, who wrote the opinion in the Appellate Court, see I Cow. 755, 756. The decree of the Chancellor was reversed on other grounds, see page 756 .

${ }^{3}$ Wiswall v. McGower, I Hoff. Ch. I25, N. Y. I839, I30, I3I, I32, I40. 
damages where, after bill brought, circumstances have rendered performance on the defendant's part impossible. ${ }^{37}$ On appeal to the Court of Appeals the Supreme Court's decision was affirmed on other grounds, the court expressly refusing to decide the point in the case to which I have adverted. ${ }^{38}$ Outside of this position of the Supreme Court of New York in the single case referred to, I know of no case in which a reference to a Master or a quantum damnificatus has been refused in the United States, where, after the agreement, and unknown to the plaintiff, the defendant put it out of his power to perform his contract. ${ }^{30}$

While Wiswall v. McGovern was in course of litigation in New York, Chancellor Walworth, in Morss v. Elmendorf, ${ }^{40}$ said that if the plaintiff was ignorant, when he began his suit, of the fact that the defendant could not be made to perform, he was not prepared to say that the fact that the defect had existed from the inception of the contract, and had not been caused by the defendant, would prevent a reference to a Master to ascertain the plaintiff's damages. The remark was aside from the facts of the case before him. The point, however, was before the courts of New Jersey in the case of Borden v. Curtis. ${ }^{41}$ There the bill was retained for the purpose of giving the plaintiff compensation. Apart from authority it would appear that, though the fact that the defendant has not wilfully deprived himself of the ability to perform removes him from the charge of wilful wrong, the basis of the decision in Denton v. Stewart remains. In proceeding in equity the plaintiff has done that which it was proper for him to do, in view of the facts known to him; there is no more reason why it is his dutty to ascertain the ability of the defendant to perform his contract in the case,

s7 Barb. 270, 1848, 281, 282.

${ }^{2}$ Reported as Price v. McGown, 1o N. Y. $465,1853,469$.

The reported American cases in which the bill was retained are: Andrews v. Brown, 3 Cush. 130, Mass. 1849, I35; Milkman v. Ordway, I06 Mass. 232, I870 (a leading case because of the care with which the opinion is written); Chartier v. Marshall, 56 N. H. 478,1876 (should be read in connection with the same case in $51 \mathrm{~N}$. H. 400, 187I).

' II Paige 277, N. Y. Ch., 1844, 288.

${ }^{2} 21$ A. 472, N. J. I89r. 
where the disability has always existed, than in the case where the defendant has wilfully created that disability.

In the New Jersey case just mentioned, the contract of which the plaintiff sought performance was for the division of land, and was by parole. The plaintiff argued that at law, damages for nion-performance could be recovered ${ }^{\mathbf{4 2}}$ though the plaintiff had shown part performance sufficient in equity to take the case out of the statute of frauds, and that this was an additional reason for obtaining damages in equity. The court refers to this argument in the course of its opinion, but does not discuss it; $;^{43}$ but, as it has the weight of considerable judicial authority, I shall refer to it at some length. As early as $18 \mathrm{I} 4$ we have a case, decided by Chancellor Kent, Phillips v. Thompson. ${ }^{44}$ There, A. allowed certain commissioners to cut a canal through his land. The damage done was to be assessed on neighboring land. There was a parole contract between $A$. and the commissioners in reference to their entry on A.'s land. A. sought specific performance. This Kent refused, on the ground of the vagueness of the contract, and because of the statute of frauds. He held, however, that the injury was done under an implied contract that compensation should be made, and issued a quantum damnificatus to ascertain this compensation, on the express ground that the statute was a bar to any recovery at law. It will be noticed that, irrespective of the bar of the statute at law, in equity the damages when found would be a lien on other lands improved by the commissioners, and that this lien was not only an additional, but in itself a sufficient ground for equitable jurisdiction. The Chancellor, however, does not refer to it. The key to the action taken by Kent is found in Parkhurst v. Van Cortland. ${ }^{45}$ In that case the plaintiff sought to enforce a parole option to purchase land on which he had made permanent improvements. The Chancellor again refuses the prayer of the bill because of the statute, and again refers it to a Master to ascertain the value of the improvements. In taking this action, he not

${ }^{12}$ See Keeler v. Tatnell, 3 Zab. 62; N. J. I850.

${ }^{43}$ Page I45.

"I Johnis. Ch. I3r, I8I4.

ts I Johns. Ch. 273, I8I4. 
only relies on Phillips v. Thompson, but refers to two earlier English cases, Hollis v. Edwards and Deane v. Izard. ${ }^{46}$ Quoting from the Lord Keeper, Kent makes him take the position that the "plaintiff in each case, had a clear equity to be restored to the money expended for improvements," (on the faith of a parole contract); that the bill would hold so far, and that he would direct "an issue at law to ascertain the damages." But a closer inspection of the cases shows that this was not the position taken by the Lord Keeper. As reported in Vernon he does assert that the "consideration" paid for the improvements should be restored, and he adds that, if damages are recoverable at law, "he should not doubt to decree it in equity," though whether by "it" he means the damage or the contract is not clear. To determine the question whether the contract can be sued on at law, he directs that the plaintiff "should declare at law upon the agreement," and then "he would consider what was further to be done in this case." In other words the cases stand for the opposite to that for which Kent used them. They would appear rather to uphold the extreme position that equity will not take up the consideration of a parole contract until the right to proceed at law is established. Indeed, from the note to the cases in the edition of Vernon's reports published in London in 1806 , it appears that the plaintiff, being nonsuited at law, the Lord Keeper dismissed the bill without costs. It is probable that Chancellor Kent did not use this edition, but the folio published in Dublin in I726.

The principle established by Kent, though partly at least an error in the interpretation of ancient authority, has been adopted by other courts. Thus in Boorerie v. Stonestreet ${ }^{47}$ a husband induced his wife to sell her land for his benefit, on the faith of a parole promise to convey other land of his to her. The man died, having failed to fulfill his promise. The woman could not at law have recovered against his estate; yet, in equity she was held entitled to a decree for the value of her land at the time she sold it, and it would seem that this decree was not to be satisfied out of any particular land of the husband's, but was to be satisfied with the claims. of

* Reported together, I Vern. I59, I683.

"6 Md. 418, 1854. 
the other creditors out of his general assets. 48 The case followed the announced principle of the two earlier cases before Kent, but unlike those cases there was no other reason, such as an equitable lien, for the jurisdiction of the Court of Chancery. ${ }^{49}$

To the writer, the fact that damages at law cannot be recovered because of the statute of frauds, is no reason why a suit for damages on the same cause of action should be brought in equity. The courts of equity may interpret the statute differently from the courts of law, but the statute is equally binding on both courts. Again, the view of the statute taken by the common law courts may be erroneous, but the court of equity has no jurisdiction to correct the errors of a court of law. That so great a jurist as Kent should have asserted that a court of equity would take jurisdiction of a suit for money damages because of the common law court's interpretation of a statute is, I believe, due to his erroneous impression that there existed English authority for the proposition. To the actual decisions of Chancellor Kent, in Phillips v. Thompson and Parkhurst v. Van Cortland, no exception can be taken. As has been pointed out, even though the respective plaintiffs could have recovered at law, they would only have recovered a judgment, while in equity they could obtain that to which they were entitled, if in view of the statute they were entitled to anything; namely, a lien on the land improved for the value of the improvements. This lien is the sole ground for the equitable jurisdiction taken in King v. Thompson, ${ }^{50}$ a case in the Supreme Court of the United States, in which the same facts appear as in the cases before Kent. Granted that the interpretation of the statute by the Court of Chancery is different from that of the common law courts, where chancery takes hold of the question it is immaterial that had the

\section{«s Page 433.}

"The Maryland court followed this decision in Green v. Drummond, 3I Md. 7r, I869, 85. See "also the action taken by the courts of Missouri in Gupton v. Gupton, 47 Mo. 40, 1870, 47, 48.

${ }^{50} 34$ U. S: 204 , I835 (no reference is made to the cases before Kent). See also to the same effect dicta in Evans v. Battle, I9 Ala. 398, 1851, 403,404 . 
plaintiff sued at law he would have been prevented from recovering a judgment because of the statute; for the court of equity is not bound to follow the interpretation given to the statute by a court of law. ${ }^{51}$ Whether the statute is or is not a bar to a recovery for the value of improvements made on the faith of an alleged parole contract by the owner of the land to sell it to the improver is a question under the statute, and one beyond the scope of our present inquiry. ${ }^{.2}$

It remains to consider the effect of the reformed code procedure, adopted in many of the States, on the plaintiff's right to obtain damages, where it is impossible for the court to decree specific performance. The only two code States in which the writer can find that the question has been discussed are New York and Wisconsin. The provisions of the practice codes in each of the States named, as far as they affect our subject, are practically identical. In each the distinction between legal and equitable remedies is expressly abolished. ${ }^{\mathbf{5}}$ There are similar provisions in relation to the proper way to set forth the form of relief demanded. It is directed that, "The complaint shall contain: A demand of the relief to which the plaintiff supposes himself to be

${ }^{*}$ Aday v. Echols, 18 Ala. 353 , I850, 357; Hilton v. Duncan, I Coldwell, 3 I3 Tenn. 1860, 320.

${ }^{82}$ Horn v. Ludington, 32 Wis. 73, 1873 , is a case in which the courts appear to adopt the converse of Kent's position in the cases discussed in the text, while at the same time following Kent to the extent of ignoring the possibility of an equitable lien. A. brought, under the reformed procedure of Wisconsin, a suit for a specific performance of a parole contract in respect to real property. He failed because he did not prove sufficient part performance to take the case out of the statute of frauds. The plaintiff was not allowed to obtain a decree for compensation for money paid and labor done on the faith of the contract. The assumption of the court is that such compensation would be legal, not equitable relief, and that the reformed procedure does not permit one to obtain legal relief in an action commenced for equitable relief. There is an apparent assumption that a suit at law for the money paid would be successful, but, as indicated, the court ignores the fact that, if the plaintiff was entitled to anything, the Court of Chancery was the only court which could give him full relief in the shape of a lien on the land for the value of the improvements made.

${ }^{53}$ New York, Chas. Pooket Code Civ. Pro., I9or, § 3339; Code Civ. Pro., 1849, § 69r ; Wisconsin, Laws 1856, Ch. 120, Preamble 
entitled." $\dot{4}$. And again, "Where there is no answer, the judgment shall not be more favorable to the plaintiff, than that demanded in the complaint. Where there is an answer, the court may permit the plaintiff to take any judgment, consistent with the case made by the complaint, and embraced within the issue." joinder of actions runs as follows: "The plaintiff may unite in the same complaint, two or more causes of action, whether they are such as were formerly denominated legal or equitable, or both, where they are brought to recover as follows: I. Upon contract, express or implied. . . . 9. Upon claims arising out of the same transaction." there are identical and liberal provisions in regard to a variance between the allegation and the proof, but this variation must not amount to a failure of proof. ${ }^{57}$ The provisions recited are typical of all of our practice codes, being found in almost the same language in each. ${ }^{58}$

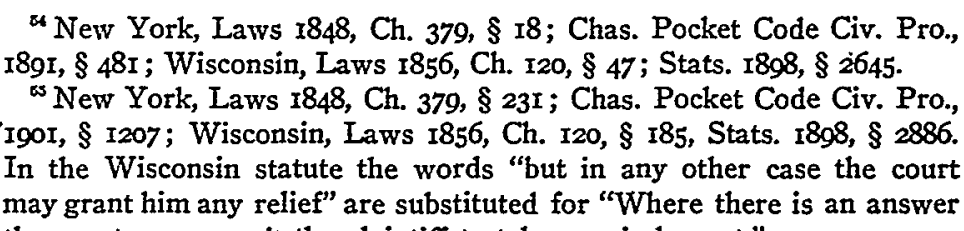
the court may permit the plaintiff to take any judgment."

${ }^{-} \mathrm{New}$ York, Chas. Pocket Code Civ. Pro., I90I, $\S 484$. In Laws I848, Ch. 379, § I43, the provision reads "The plaintiff may unite several causes of action in the same complaint where they arise out of, x. Contract express, or implied." The clause in relation to "the same transaction" does not appear. See also Laws $1849, \mathrm{Ch} .438$, § 107. In Rev. Stats. 1859, Vol. III, Code Civ. Pro., $\$ 16 \%$, the language in respect to "legal or equitable" actions was adopted. In 1877 the language as quoted in the text was adopted, see Laws 1877 , Vol. II, Code Civ Pro., $\S 484$. Wisconsin Stats. I898, § 2647. This code uses the words "several causes of action," instead of the words "two or more," the words "where they arise out of" instead of "where they are brought to recover," and "the same transaction or transactions connected with the same subject of action," instead of the ninth sub-head of the present New York wording. In Wisconsin the language of this section as now in force has existed from the adoption of the first code of practice, see Laws $1856, \mathrm{Ch}$. 120, § 73 .

${ }^{57}$ New York, Laws I848, Ch. 379, §§ I45, I46, I47, Chas. Pocket Code Civ. Pro., I901, 539, 540, 541; Wisconsin Stats. 1898, $\$ \S 2669$, 2670, 267I; Laws I856, Ch. I20, \$§ 77, 78, 79.

w See Bryant's Code Pleading, Cal., I899, pp. 352, 353. 
Perhaps the first case to mention the effect of these provisions on the right to recover damages in an action for a specific performance was Hall v. Delaplaine, decided in Wisconsin in 1856.59 In the case in question, A. agreed to buy land from $B$. B. conveyed to $C$. A. brought a bill for specific performance, making B. and C. defendants, and alleging that $\mathrm{C}$. took with notice. At the trial A. failed to proye that $C$. took with notice. The bill was dismissed as to C., but ultimately retained against B. for the purpose of assessing damages. The court express the opinion that they would have retained the bill anyhow, but that since the code procedure went into effect, and there is no separate court of equity, there is an additional reason for retaining the bill. New York, however, seems to have been first to apply the code so as to permit a recovery of damages, where, had the old practice prevailed, the plaintiff would have been sent to law. In Barlow v. Scott, ${ }^{\circ 0}$ the plaintiff asked for specific performance or damages. On the face of the complaint the plaintiff showed that he could only be given damages. The defendant put in an answer. The court permitted the plaintiff to recover damages. This case was followed in a few years by the decision in Genet v. Hozeland, ${ }^{61}$ where in a case like Barlowe v. Scott, except that the plaintiff did not ask for damages, he was, nevertheless, permitted to recover damages, a specific performance on the face of his bill being impossible. ${ }^{62}$ In Sternberger v. McGovern, ${ }^{63}$ the complainant set out a contract and asked for specific performance, or other relief. At the trial it developed that the plaintiff when he brought his action knew that the defendant could not perform his contract. The trial court on this ground refused to retain the case for the purpose of assessing damages. On appeal this action was reversed and a new trial ordered. The court point out that the code authorizes the

${ }^{50} 5$ Wis. 206,1856 .

${ }^{\infty} 24$ N. Y. $40,186 \mathrm{r}, 45$.

${ }^{21} 45$ Barb. 560, 1866, 568-573.

"It is expressly recognized in both these cases that under the old practice damages could not have been recovered: 24 N. Y., p. 45 , and 45 Barb., p. 568.

${ }^{\infty} 56$ N. Y. $12,1874,20,21$. 
uniting of causes of action, both legal and equitable, arising out of the same transaction in the complaint. They admit that the facts constituting these causes of action must be stated in the complaint, ${ }^{64}$ but assert that in the case before them the plaintiff did this, by fully setting forth the contract. ${ }^{65}$ During the same period the Supreme Court of Wisconsin had come to similar conclusions. ${ }^{86}$

The cases just referred to are all examples of cases in which the defendant answered. From them one may infer that probably in all code States, once the plaintiff answers, any relief consistent with the case alleged and proved can be given, whether that relief is legal or equitable. In Horn v. Ludington, ${ }^{67}$ however, the plaintiff asked for specific performance of a verbal contract in respect to land without

"Pointing to Bradley v. Aldrich, 40 N. Y. 504, 1869, as a case in which this was not done.

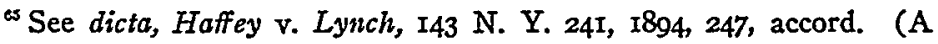
good résumé of the matters under discussion in text.) In Miles v. Dover Furnace Iron Co., I25 N. Y. 294, I891, the plaintiff brought his bill for specific performance or, if that was impossible, damages. The court in granting him damages say: "The plaintiff in his complaint asked, as he had a right to, both damages for a breach of the entire contract and a specific performance of a single branch of it, and himself raised the question which relief should be 'granted, and made admissible all the facts of the situation bearing upon the alternative and the exercise of the discretion invoked." P. 298.

${ }^{68}$ In Leonard v. Rogan, 20 Wis. 540 , 1866, 542, one who asked for equitable relief, but showed himself entitled to legal relief, was given legal relief. In Hopkins v. Gilman, 22 Wis. 476 , 1868 , the plaintiff in his complaint set forth an agreement by a lessor to take certain improvements made by the tenant at a valuation, valuers to be appointed by both parties. On its face, this was not a contract of which a court of equity gives a specific performance. The court retained the bill for the purpose of assessing the value of the improvements as damages. $\mathrm{Pp}$. $48 \mathrm{r} ; 482$. Note that the value of the improvements was an equitable lien on the land. The enforcement of this lien would be an equitable relief, though not that equitable relief which the plaintiff had demanded. This phase of the case, however, is not referred to by the court. See ante, note 50 .

In Stroebe v. Fehl, 22 Wis. $337,1867,348$, the plaintiff demanded both legal and equitable relief, setting forth facts which would have entitled him to both; he only proved facts sufficient to give him legal relief. $\mathrm{He}$ was held entitled to this relief.

${ }^{6}{ }_{32}$ Wis. $73,1873,79$. 
setting out sufficient part performance to take it outside the statute of frauds. The court assume that the complainant did set out facts which would warrant the return in a legal action of an equivalent for money expended. The defendant demurred. Counsel and court agree that the demurrer must be sustained if the plaintiff cannot show ground for equitable relief. This position is taken apparently on the ground of the express provision in the code requiring the relief on demurrer to be limited to that demanded by the plaintiff. ${ }^{8}$ There would appear to be no reason why this case should not be followed in all jurisdictions having the provision of the code referred to. ${ }^{69}$ It has, however, been held in New York that where the plaintiff asks for specific performance or damages, whether he sets out facts which entitle him to one or both, the complaint setting out a clear cause of action; it is not demurrable. ${ }^{70}$ In Wisconsin, however, it has been held, that where the plaintiff asks for legal or equitable relief, the complaint on its face showing him to be entitled to legal or equitable relief, but not both, the complaint is demurrable. ${ }^{71}$ The New York position would appear at first glance to be in accordance with the general object of code procedure. ${ }^{72}$ On the other hand

- Compare Tenney v. The State Bank, 20 Wis. I52, $1865,163,164$.

" Note statement to the contrary by Pomeroy, see his Spec. Per., \$ 48I, ed. I897. An objection that there is an adequate remedy at law can be raised in the answer. If a plaintiff asks for equitable relief, as for a specific performance, showing on the face of the complaint that he is only entitled to legal relief if any, the objection "of adequate remedy at law" would appear to be final. See Witherbee v. Meyer, 84 Hun, 146, N. Y. I895.

"See Mozvbray v. Funston, 9 N. Y. App. Div. 120, 1896, where such a demurrer was said to be "without merit." This case sets at rest the doubt which may arise from reading Styles v. Blume, 30 N. Y. Sup. 409, I894, whether such a complaint is not demurrable.

in Johns v. Northwestern Relief Asso., 87 Wis. III, I894, II3.

2 All jurisdictions would probably follow Wisconsin in refusing to permit a plaintiff, setting forth facts showing that he is entitled to equitable relief, to prove a totally different course of action and obtain legal relief. Here there would be a variance which amounted to failure of proof, a contingency for which as has been seen (note 53, supra) the code provides: Carmichael v. Argard, 52 Wis. 607, 1881; Kavanagh v. O'Niel, 53 Wis. IOI, I88i, I06. 
the Wisconsin position has behind it the positive provision of the code that issue's of fact, involving a demand for a sum of money; shall go to a jury at the request of either party, while a question involving the relief of specific performance must be tried by reference. It follows that unless the defendant knows which relief is to be demanded, he does not know the kind of trial he has a right to insist on.

The reference to the subject of trial by jury brings us to the one circumstance in which the new procedure may be considered as narrowing the scope of what we may call purely equitable proceedings leading to the recovery of damages. Where, under the old practice, a court of equity gave damages, the judge, while he may have had the right to refer the question of the assessment of the amount of damages to a jury, was not obliged to do so. A large number of the practice codes, however, as just pointed out, contain a provision, that issues of fact for the recovery of money must go to a jury. ${ }^{73}$ Under this clause it was held in Stevenson v. Buxton, ${ }^{74}$ that where the defendant, in his answer to a bill to compel the conveyance of land, sets out that he never had any title, the court may retain the bill, but, on demand of the defendant, must send to a jury to assess damages. ${ }^{75}$ The right to demand a jury trial may be waived by not demanding it. ${ }^{78}$ The case of O'Beirne v. Bullis presents an extreme example of this principle. In that case the plaintiff, not knowing that the defendant since the contract had parted with the land, brought an action for a specific performance of the contract of sale. The lower court refused to retain the bill for the purpose of assessing damages. It will be noticed, that even under the old practice this bill

${ }^{78}$ A full reference to these statutes will be found in a previous article. See ante (February number) 49 AM. LAW REG., 1902, 83, note 85.

74 Barb. I3, N. Y., I86I.

"In this case, as the defect had existed from the inception of the contract, it is of-course impossible to say positively whether the court would or would not have assessed damages under the old practice, See further as to the right of either party to demand a jury trial in cases where under the old practice equity would not have retained for the assessment of damages: Stermberger v. McGovern, 56 N. Y. 12, I874, 2I ; Haffey v. Lynch, I43 N. Y. 241, I894, 247.

${ }^{70}$ See, for example, Barlow v. Scott, 24 N. Y. 40, I86r. 
would have been retained, at least in most jurisdictions. ${ }^{77}$ On appeal this action was reversed and the case remanded for trial. ${ }^{78}$ When the case came again before the lower court the defendant demanded a jury trial. This was denied, and on appeal the denial was sustained, because the defendant should have demanded a jury trial when the question of the amount of damages first came before the court. ${ }^{79}$ Whatever may be said as to this application of the rule regarding waiver of the right to a jury trial, it will be noticed on a reading of the case, that the court assumes that, had the defendant demanded a jury trial at the right time, he would have been entitled to it. This is the nearest case known to the writer on the question whether under code procedure the defendant has a right to a jury trial in a case where under the old practice the court of equity would have assessed damages in lieu of a specific performance. In view of the apparent practical absence of authority, no positive answer can be given to the question..$^{80}$

In concluding the subject it is, perhaps, proper to mention - the fact that there are some cases in the code States, in which the court has applied the rules of the old equity practice in awarding damages where a specific performance is impos-. sible. In most of these cases, as will be seen in the note, no reference is made to the effect of the Practice Code in widening the power of the court in respect to its ability to award damages. ${ }^{31}$

William Draper Lezris.

"Query as to New York, see ante, note 38.

${ }^{78} 80$ Hun, 570, N. Y. 1894.

"2 App. Div. 545, N. Y். I8g6. Compare Witherbee v. Meyer, 84 Hun, 146, N. Y. 1895 .

${ }^{80}$ See, for a reference to some conflict in respect to the meaning of the provision in regard to jury trials, the article ante (February number). 49 Ais. LAW REG., 84, note 86.

"O'Meara v. North American Mining Co., 2 Nev. I12, 1866, 117; Hamilton v. Hamilton, 59 Mo. 232, 1875. (Dicta. The case referred to by the court, Holland v. Anderson, $38 \mathrm{Mo}$. 55, 1866, has to do with an award of damages where, owing to the alteration in the subjectmatter of the sale, its cancellation, otherwise proper, is impossible.) Cumningham v. Duncan, 4 Wash. 506, 1892 (reversing the dicta in Morgan v. Bell, 3 Wash. 554, $18 \mathrm{~g} 2$, in which the position of the Supreme Court of Maine, in Woodman v. Freeman, $25 \mathrm{Me}$. 531, 1846, that, to 
award damages in lieu of specific performance, the circumstances must have been such at the time of the filing of the bill as to have enabled the court to grant specific performance). No reference is made in any of these cases to the code. It may be noted that in Washington the clause in reference to the joinder of actions omits the statement, "whether formerly denominated legal or equitable," as well as the clause in reference to "arising out of the same transaction." See Hill's Anno. Code and Stats., I89I; Code of Civ. Pro., Ch. VII, § 2I4; Ballinger's Anno. Codes and Stats., Wash., I897, $\S 4942$. The other clauses bearing on the subject under discussion are similar to the New York Code, see Hill (ib.), §§ 188 , 219.

Thresher v. Stonington Savings Bank, 68 Conn. 201, 1896, 204, 205 , is another instance of an award of damages in a' case. where the award would have been proper under the old practice. Reference is here, however, made to the new procedure as an additional reason for the relief. 